\title{
Akar-akar Kanan daripada Nasionalisme Indonesia: Nasionalisme Jawa dalam konteks kesejarahannya
}

\author{
Farabi Fakih \\ Staf Pengajar Jurusan Sejarah, Fakultas IImu Budaya, Universitas Gadjah Mada, Yogyakarta
}

\begin{abstract}
Abstrak
This papers explores the thoughts of Javanese nationalists during the early phase of Indonesian nationalism. It will specifically look into the ideas of Tjipto Mangoenkoesoemo and Noto Soeroto as prototypes of new nationalist sentiments that grew during a period of intense revolutionary fervor, marked by the rise of marxism and fascism throughout the world. By looking at these factors, it wants to situate the global roots of Indonesian nationalism and contextualize Indonesian nationalist history within the global development of the early twentieth century.
\end{abstract}

Kata kunci: Nasionalisme Jawa, Pergerakan Nasional, Marxisme, Irasionalisme.

\section{Pendahuluan}

Ini adalah artikel eksploratif mengenai akarakar daripada nasionalisme Indonesia. Artikel ini berkembang dari ide yang diajukan oleh penulis pada karangan tesis MPhil-nya di Universitas Leiden, yang sebagian sudah diterbitkan dalam jurnal BKI terbitan KITLV. Tesis yang diajukan adalah bahwa akarakar daripada nasionalisme Jawa itu dapat ditemukan sebagai akibat daripada interaksi Barat dengan Jawa sepanjang abad ke19 dan produksi pengetahuan Barat yang menghantam legitimasi daripada kerangka produksi pengetahuan Jawa. Yang menarik adalah bahwa akar-akar daripada nasionalisme Indonesia ditemukan bukan pada spektrum yang biasa ditempatkan: di-spektrum politik kiri, melainkan bahwa ia berkembang pada spektrum politik kanan. Spektrum kanan Indonesia, yang pertama kali berkembang dalam bentuk nasionalisme Jawa, tetap mempunyai cengkraman yang kuat dalam nasionalisme Indonesia sekarang ini. Ada usaha penerapan ide-idenya dizaman Orde Baru. Akarnya yang berkembang diawal abad ke-20 dan ketertarikannya pada ide-ide irasional menyebabkan adanya paralel yang kuat dengan gerakan-gerakan fasis yang berkembang diberbagai tempat lain didunia.

Cara kita memahami sejarah dari perkembangan nasionalisme di Indonesia akan diperkaya jika kita dapat menempatkannya dalam konteks menguatnya dua tipe model hubungan negara dan bangsa yang berkembang pada awal abad ke-20. Artikel ini akan membahas tiga pendekatan yang muncul dalam kalangan ningrat Jawa sebagai akibat daripada modernitas. Pertama, kemunculan pendekatan irasional yang didorong oleh ningrat konservatif macam Soetatmo Soerioekoesoemo. Kedua, reaksi terhadap konservatisme ini lewat pendekatan revolusioner lewat pengimporan analisis Marxis, seperti yang terjadi lewat kritikan Tjipto Mangoenkoesoemo. Dan terakhir, kita akan mengeksplorasi ideide utama Noto Soeroto, sebagai anti-tesis daripada ide-ide non-koperasi yang menguat di Indonesia.

Nasionalisme Indonesia itu berkembang pada zaman ketika nasionalisme itu menguat 
diseantero dunia. Mengikuti tren yang sama, terjadi dorongan yang kuat pada spektrum 'kanan' dan 'kiri', i.e. yang sama-sama revolusioner (Griffin, 2007: 91-95, Roberts, 2010: 183-201). Jika kita dapat menempatkannya dalam kondisi perkembangan ini, maka kita dapat menempatkan sejarah perkembangan nasional Indonesia dalam konteks globalnya. Tahun-tahun 1918-1940 adalah masa penguatan spektrum kiri dan kanan yang diwakili oleh Komunisme dan Fasisme. Griffin menyebutkan rapatnya akar-akar totalitarianisme Fasisme dan Komunisme di Eropa (Griffin, 2007: 63). Ekplorasi dari nasionalisme Indonesia harus mempertimbangkan aspek ini sebagai bagian dari sejarah global. Jika kita dapat memahami dan memaklumi akar-akar beragam nasionalisme kita, maka sebagai bangsa kita dapat pula mengembangkan jiwa kritis dan rasa takut, takjub dan hormat terhadap ideologi kebangsaan agar tidak digunakan untuk tujuan-tujuan yang merugikan bangsa sendiri pula. Sebagai bagian daripada reaksi modernitas, kita harus mencoba mencari akarakar kebangsaan itu pada puncak daripada zaman modern dan liberal Eropa: pada abad ke-19.

\section{Produksi Pengetahuan Barat dan Modernitas: Jawa Palsu?}

Pergolakan masyarakat di Indonesia pada akhir abad ke-19 dan awal abad ke-20 itu berkembang pesat. Petrus Blumbergen menghitung beberapa reaksi 'pra-modern' yang muncul: Ratu Adil, Saminisme serta serangkaian revivalisme relijius yang berakar pada permasalahan yang diakibatkan oleh masuknya dunia modern ke-dalam lingkungan terpencil dalam masyarakat Indonesia. Blumberger membagi hal itu dengan reaksi yang modern dan terorganisir. Dalam hal ini, reaksi organisasi modern tersebut adalah rasional dan fokus pada beragam kegiatan yang bertujuan mengangkat harkat dan martabat anggotanya, serta mengembangkan kegiatan sosial, ekonomi, budaya dan politik. Sementara reaksi pra-modern itu didasarkan atas dorongan-dorongan tradisional atau irasional yang ephemeral dengan organisasi yang sederhana dan rapuh (Blumberger, 1931).

Tapi organisasi modern itu bereaksi terhadap modernitas yang sama. Modernitas dapat diartikan disini sebagai sebuah cara pandang yang bertumpu pada rasionalitas, ilmu pengetahuan Barat, logika Barat dan berakar dari filsafat-filsafat yang berkembang di Barat pada masa Pencerahan. Oleh karenanya, pandangan modern ini seringkali terikat pula dengan ide-ide yang mengangkat individu sebagai agen utama dunia.Sebagai sebuah program politik, Pencerahan yang berkembang di abad ke-18 Barat itu menghasilkan dua reaksi besar terhadap 'feodalisme' ancien regime yang berkuasa.Pertama adalah reaksi yang berkembang di Inggeris dan menghasilkan apa yang disebut Liberal Klasik. Dalam pandangan ini, feodalisme dapat dibatasi dengan mengangkat hak individual dan membatasi peranan negara. Kedua adalah reaksi yang berkembang dalam Revolusi Perancis yang menginginkan peran serta negara yang lebih besar sebagai pendorong perubahan-perubahan progresif dalam masyarakat.Ini adalah akar dari sosialisme yang menempatkan negara ataupun komunitas sebagai lembaga yang dapat mengangkat harkat dan martabat manusia (Outram, 2013: 1-9).

Pada abad ke-19, liberalisme klasik mengalami masa kejayaan. Ide-ide utamanya: hak asasi manusia, perdagangan bebas, pembatasan negara menjadi night watchman state, tercapai diberagam tempat. Tetapi hal tersebut tidak terjadi di Hindia Belanda. Ideide liberal pertama kali diajukan oleh Reformis macam Dirk van Hogendorp ketika Belanda dibawah Republik Bataafsche yang terpengaruh dengan ide-ide revolusi Perancis. Ketika Jawa dibawah Inggeris, Thomas Stanford Raffles berusaha memperkenalkan serangkaian reformasi liberal yang bertujuan mengangkat 
petani Jawa sebagai individu modern dengan memberikan mereka hak milik atas tanah dan memonetisasi hubungan mereka dengan negara dan masyarakat lewat pajak tanah. Reformasi liberal awal abad ke-19 itu gagal dan van den Bosch lalu memperkenalkan serangkaian aturan kepemilikan tanah dan kewajiban kepada negara yang bersifat konservatif dan memperkuat struktur feodal Jawa. Walaupun sistem tersebut dihentikan pada akhir abad ke-19 dengan, akhirnya, berjayanya liberal klasik di Hindia Belanda, tapi struktur feodal pemerintahan pribumi malah diperkuat (lihat: Furnivall, 2010).

Pada saat ketika konservatisme politik menguat, ekspansi daripada produksi pengetahuan Barat itu menggerus legitimasi kekuasaan struktur feodal Jawa.Ilmu seperti etnologi ataupun linguistik berkembang pesat dibawah arahan ilmuan-ilmuan Barat yang bekerja di beragam lembaga pengetahuan yang muncul di Jawa. Penemuan akankeluarga bahasa merangsang pembentukan gambaran global akan struktur rasial manusia dan, pada saat bersamaan, memberi posisi tiap-tiap ras pada skala vertikal yang menandakan kecanggihan ataupun keprimitivan tiap ras. Penemuan keluarga bahasa Indo-Eropa oleh Sir William Jones pada akhir abad ke 18 mengarah pada penemuan daripada ras Arya atau ras kulit putih oleh Max Muller di Jerman pada tahun 1840 an. Indo-Eropa menempatkan India sebagai salah satu pucuk daripada ras Arya dan bahasa Sansekerta sebagai salah satu pucuk dari bahasa dunia, setara dengan Yunani dan Latin. (Edgerton, 1946: 230-239, Tull, 1991: 27-58, Muller, 1888: 120, Ballantyne, 2002: 22 23, Errington, 2008: 84).

Naiknya India sebagai salah satu pucuk peradaban ras Arya menyebabkan sesuatu yang menarik pada Jawa. Jawa menempatkan posisi yang skizofrenik dalam wacana pengetahuan kolonial.Thomas Stanford Raffles dalam magnum opusnya, The History of Java, menunjuk pada kejayaan Jawa dimasa lalu dengan karya seni dan budaya seperti candi-candi megah ataupun literatur yang tua. Tujuan utama Raffles adalah menunjukkan orang Jawa sebagai ras yang penuh potensi dan yang bisa berkontribusi pada tingkat individual. Raffles adalah penganut ide-ide liberal Adam Smith dan percaya bahwa ketika diberi-tanggung jawab, ras Jawa akan dapat berperan serta dalam persehubungan bangsa-bangsa. Tapi dalam proses ini, Raffles mengangkat Jawa diatas beragam ras-ras di Hindia Belanda lainnya (Raffles, 1815: 2324; Raffles, 1965: 57). Dengan menempatkan kehebatan Jawa, ia menempatkan ras dan budaya Jawa sebagai yang terpenting dan tertinggi di kepulauan Indonesia. Ini juga terlihat pada diskusi mengenai beragam ras/ etnis/budaya di Hindia yang diangkat oleh salah seorang ilmuan Belanda terkemuka, P.J. Veth.Dalam magnum opusnya, ras Jawa ditempatkan dalam skala vertikal yang tertinggi diantara ras-ras lain di Indonesia (Veth, 1907: 35-38, 56, 74, 216).Penempatan Jawa ini punya beragam maksud.Posisi ini akan diambil alih oleh sebagian ningrat Jawa sebagai pembenaran daripada penguasaan mereka terhadap pemerintahan pribumi.

Buat Raffles gambaran ini adalah untuk meyakinkan pentingnya mendorong orang Jawa agar maju dan mandiri sesuai dengan ide-ide liberal. Pada pertengahan abad ke-19, banyak daripada ide-ide didorong oleh kebutuhan untuk membenarkan berjalannya feodalisme Jawa di Indonesia sebagai pendukung daripada struktur ketata-negaraan Hindia Belanda, tetapi pada saat yang bersamaan, penjunjungan tinggi kebudayaan Jawa asli, yaitu Jawa adiluhung, digunakan sebagai cara untuk mengkontraskan dengan kebudayaan populer Jawa sekarang yang didasari atas Islam. Jawa Adiluhung adalah Jawa tua yang Hindu-Buddha.Sementara Jawa sekarang adalah Jawa lemah yang korup.Korupsi Jawa diakibatkan karena berpindahnya Jawa dari Hindu-Buddha atau koneksi subordinatnya 
kepada sebuah dunia India kepada peradaban Islam dan hubungannya dengan dunia Semitik. Pada sekitar 100 tahun terakhir kekuasaannya di Hindia Belanda, rasa takut akan hancurnya proyek kolonial akibat dari serangan Jawa yang didorong oleh fanatisisme Islam menghantui pemerintah dan masyarakat kulit putih atau Indo yang kecil itu.

Pada saat yang lain, dunia etnografi Belanda mencibir posisi orang Jawa. Mereka digambarkan sebagai orang indolen atau pemalas, yang tidak rasional dan penuh dengan takhayul, yang tidak mampu mengontrol nafsu baik seksual ataupun lainnya.Pendekatan rasial yang semakin mencengkram wacana hubungan antar-manusia dalam masyarakat kolonial menyebabkan tergerusnya posisi orang Jawa atau kulit sawo matang dalam pergaulan antar-manusia ataupun dengan negara.Rasa takut akan verindlandschendikalangan Indo diwujudkan dengan perasaan takut yang dalam akan hal seperti warna kulit, aksen bahasa Belanda yang baik dan tampilan luar lainnya. Pandangan negatif akan masyarakat dan manusia Jawa itu seringkali menyebabkan kritikan terhadap ilmuan-ilmuan Belanda dimana sanjungan terhadap budaya Jawa dilihat sebagai suatu verinlandschen tersendiri dari ilmu pengetahuan Barat di Indonesia (Buskens \& Kommers, 2007: 358).

Ekspansi produksi pengetahuan Barat khususnya pada akhir abad ke-19 mulai menggerus produksi pengetahuan lokal.Brandes menyangsikan kebenaran daripada babad Jawa.Karena tercampurnya diskursus sejarah dengan mitologi orang Jawa, keseluruhan daripada korpus sejarah Jawa diragukan.Intiinti dari peradaban Jawa itu diragukan keasliannya.Budaya Adiluhung Jawa dijadikan hanya kopian daripada budaya India yang berakar daripada ras Indo-Eropa atau Arya. Cerita utama peradaban Jawa; Ramayana dan Mahabharata, merupakan impor dari India. Serangan terhadap kesahihan akar-akar budaya Jawa ini lewat 'rasionalitas' dan 'logika' ilmu pengetahuan Barat itu amat dashyat. Pada akhir abad ke-19, ningrat-ningrat Jawa yang berkeinginan mempertahankan posisi mereka sebagai punggawa koloni Hindia Belanda mulai mengirimkan anak-anak mereka ke sekolah Belanda.Banyak diantara mereka yang mengganti pandangan-dunia (world-view) mereka dengan menyesuaikan pada pandangan-dunia Barat yang lebih superior.Ranggawarsita menjadi pujangga kraton terakhir Jawa. Lebih menakjubkan lagi, cucu daripada golongan elit Jawa ini pada akhirnya akan menolak kebudayaan Jawa sehingga dalam transisi menuju negara merdeka dan budaya nasional, budaya feodal Jawa tersisihkan.

Sementara itu penemuan sejarah kejayaan masa lampau Jawa lewat ditemukannya karya-karya lama macam Negarakrtagama menguatkan pelemahan Jawa sebagai akibat daripada Islamisasi serta memperkuat ide-ide bahwa Jawa butuh bimbingan orang-orang Arya, yang dahulu kala diberikan oleh orangorang India lewat 'kolonisasi' mereka terhadap kepulauan Indonesia. Ide ini digunakan oleh beberapa orang Belanda untuk menyokong argumen bahwa keberadaan orang Belanda di Indonesia sama dengan keberadaan orang India pada masa kejayaan Jawa dahulu kala. Sejarah dan pengetahuan Jawa digunakan oleh membenarkan keberadaan orang Belanda dan kolonisasi Jawa dan Indonesia.

\section{Reaksi terhadap Hilangnya Adiluhung: Irasionalisme}

Ekspansi daripada pendidikan di Indonesia semenjak akhir abad ke-19 lebih banyak mempengaruhi aristokrat Indonesia beserta anaknya, khususnya aristokrat Jawa. Walaupun ada banyak protes sosial/ekonomi/ politik terhadap keadaan kolonial di Jawa semenjak awal abad ke-19, protes tersebut diekspresikan dalam bentuk tradisional macam gerakan-gerakan mileniaris atau ekspresi tradisional akan ide-ide yang sama muncul 
di Eropa macam gerakan Samin (King, 1973: 457-481). Dalam pantheon sejarah kebangkitan kebangsaan, Boedi Oetomo diangkat sebagai titik awal daripada kebangkitan bangsa Indonesia pada tahun 1908. Tetapi Boedi Oetomo adalah organisasi ningrat yang banyak berisi anggota Pamongpradja beserta anak-anak mereka. Lebih penting lagi, Boedi Oetomo adalah gerakan kebudayaan yang mencoba menjawab permasalahan paling pelik yang dihadapi oleh orang-orang Jawa pada masa itu: eksistensi dan legitimasi budaya Jawa dari serangan rasionalitas ilmu pengetahuan Barat. Sepanjang dekade-dekade awal kebangkitan bangsa, serangkaian kongres kebudayaan diselenggarakan oleh Boedi Oetomo atau organisasi kebudayaan Jawa lain guna menjawab tantangan modernisasi masyarakat dan kebudayaan Jawa tanpa harus menghilangkan akar-akar daripada kebudayaan tersebut. Pada pandangan lebih lebar lagi, pertanyaan mengenai bagaimana menghadapi modernitas dan modernisasi ini adalah masalah pelik yang dihadapi semua umat manusia pada zaman ini.

Permasalahan akan penggerusan 'mitos' yang disediakan oleh kepercayaan tradisional itu adalah fenomena global. Analisis rasional lewat ilmu pengetahuan menghancurkan fondasi pandangan-dunia yang dianggap tidak rasional.Hal itu termasuk pula pandangandunia Kristen di Barat sendiri.Naiknya ras dan keluarga bahasa beriringan dengan menguatnya sentimen-sentimen nasionalis, salah satu ekspresinya terungkap lewat imperialisme akhir abad ke-19. Di Indonesia, gerakan imperial ini menyebabkan munculnya Pax Neerlandica dan 'selesainya' kolonisasi kepulauan-kepulauan di Nusantara dibawah Gubernur van Heutz. Nasionalisme dan romantisisme ras yang terbentuk pada abad ke-19 merupakan bagian daripada usaha penolakan proyek pencerahan yang rasional dan modern.Umat diganti dengan bangsa.Di beberapa negara yang baru tercipta menjelang akhir abad ke-19 macam Jerman dan Italia, ada keinginan untuk menciptakan mitos-mitos nasional baru.Pencarian terhadap ur-Jerman ataupun ur-Italia itu berlangsung bersamaan dengan naiknya imperialisme akhir abad ke-19.Ekspresi pencarian kejayaan masa lalu kebangsaan itu bersifat romantis dan merupakan anti-tesis daripada rasionalitas pencerahan.Bahkan, ada perayaan terhadap sifat irasional sebagai ekspresi kebebasan daripada pengekangan cara-pandang pencerahan yang tidak dapat memberi makna bagi kehidupan manusia kebanyakan (Lerner et.al, 1988: 809-844)

Dalam kondisi inilah ningrat Jawa bangkit untuk menjawab anomie yang ditimbulkan oleh produksi pengetahuan Barat. Rasa pesimis yang mendalam pada abad ke-19 oleh kalangan ningrat Jawa itu digambarkan dalam puisi terakhir Ranggawarsita. Tetapi pada abad ke-20, orang-orang Jawa yang terbaratkan dan fasih berbicara dan berbahasa Belanda dan bahasa Eropa lainnya, mulai mendapatkan jawaban yang lain terhadap anomie itu. Mereka menemukan irasionalitas sebagai jawaban; khususnya dalam gerakan Teosofi.Nyonya Blavatski yang berasal dari Rusia adalah penemu dari gerakan ini. Dalam serangkaian kitab yang diproduksinya, Blavatski menggambarkan sebuah dunia berisi mahluk-mahluk yang berasal dari planet lain yang mengawasi manusia. Sebuah mitos baru diciptakan guna membangun pandangan-dunia baru yang berbeda. Lebih penting lagi, Teosofi punya ketertarikan luar biasa terhadap Asia, khususnya filsafat dan budaya moralnya yang dianggapnya merupakan akar dari peradaban yang telah hilang dalam peradaban Barat yang materialis dan rasional.

Kalangan Teosofi, seperti Henry Steel Olcott dan Annie Bessant hijrah ke India dan beragam negara Asia lainnya dalam usahanya menemukan akar-akar spiritual Timur guna melengkapi kekosongan Barat.Di India, mereka berperan penting dalam kemunculan 
nasionalisme Hindu. Pemitosan kebangsaan Hindu merupakan salah satu akar penting daripada nasionalisme India.Di Indonesia, Teosofi muncul sejak tahun 1883 di Pekalongan dan pada awalnya didorong oleh orang Eropa ataupun Indo. Ningrat Jawa, kalangan Tionghoa dan orang-orang Buddha akan juga terdorong untuk berpartisipasi aktif, termasuk banyak dikalangan nasionalis Jawa, macam Soetatmo Soerioekoesoemo, Tjipto Mangoenkoesoemo dan lain-lain. Gerakan itu dianggap sebagai kunci oleh banyak kalangan nasionalis Jawa dalam usaha melewati modernitas dan modernisasi tanpa harus kehilangan akar-akar kebudayaan Jawa itu sendiri (de Tollenaere, 1996: 100-110). Penempatan Asia sebagai akar dari spiritualisme tua merupakan sebuah fenomena yang akan terus berlanjut di Barat. Pasca Perang-Dunia ke-II, usaha untuk mencari Timur yang asli dan spiritual itu akan menjelma menjadi hippie-trail, sebuah tradisi pilgrimage yang dilakukan ribuan orang Barat ke India, tetapi juga negara-negara lain seperti Indonesia (khususnya Bali) dalam usaha mereka mencari spiritualitas. Proses ini akan mengimpor serangkaian budaya baru di Barat seperti guru-guru spiritual dari India ataupun praktek macam Yoga atau Tantri. (Vickers, 1989; Hitchcock \& Putra, 2007: 25-38).

Van Hinlopen-Labberton, salah satu pendorong teosofi dikalangan ningrat Jawa, aktif menulis dan menganalisis budaya pra-modern Jawa sebagai ekspresi untuk menciptakan nasionalisme baru (de Tollenaere, 1996: 30). Tulisannya berusaha merekonsiliasi keadaan Islam Jawa dengan Teosofi (HinloopenLabberton, 1909: 3-14).Berbeda dengan tulisan kalangan ilmuan Belanda yang berusaha menunjukkan peluruhan peradaban IndoEropa di Jawa sebagai akibat dari Islamisasi, Teosofi menjanjikan perdamaian antara kedua itu.Soetatmo, merujuk pada kenyataan bahwa banyak kalangan orang Eropa terpelajar yang setuju dan tertarik dengan Teosofi, menolak ilmu pengetahuan Barat sebagai penentu satu-satunya kebenaran. Ia membela babad Jawa, sebagai contoh, sebagai sebuah cara pengetahuan yang berbeda dengan yang lazim dilakukan di Barat dan bahwa ada batasan kemampuan pembacaan Barat terhadap budaya Jawa itu sendiri. Menurut Soetatmo ada kemampuan membaca yang tidak berdasar pada rasionalitas tetapi berdasar pada spiritualitas, sesuatu yang sulit dipahami oleh orang Barat rasional (Soeriokoesoemo, 1921: 11-14).

Lewat klaim spiritualitas Timur, ningrat Jawa dapat mengambil alih kembali sejarah Jawa itu sendiri.Barat yang bobrok sebagai akibat dari materialisme dan rasionalitas tidak mungkin menjadi pewaris daripada spiritualitas Hindu-Buddha yang berakar dari India.Spiritualitas Timur itu masih hidup dikalangan masyarakat Jawa dan oleh karenanya kebesaran daripada Majapahit dapat direklaim kembali.Daripada membenarkan kolonialisme, cara pandang ini membenarkan persehubungan yang berlanjut dengan Jawa tetapi dengan posisi yang dibalik. Sekarang Baratlah, sebagai peradaban yang muda dan belum matang, yang mencari dari Jawa butirbutir kaidah dan pemahaman peradaban tua. Persehubungan kolonial menjadi sesuatu yang jauh bersifat adil. Daripada rasa malu dan anomie, Jawa dapat bangkit kembali sebagai partner dalam persehubungan Hindia Belanda yang menyegarkan.

Pendekatan kebudayaan inilah yang menjadi akar daripada nasionalisme Jawa. Nasionalisme Jawa ini bersifat konservatif.Ia tidak berusaha untuk mendorong perubahan, melainkan mempertahankan keadaan. Ada kesepatakan bahwa bangsa Jawa itu lemah dalam hal kemampuan teknik dan sehingga membutuhkan bantuan daripada bangsa Belanda.Kartini meminta Belanda untuk membantu bangsa Jawa bangkit dari keterpurukan (Kartini, 1976: 19-36). Sebagai sebuah proyek penciptaan mitos, ia adalah hasil kerja sama dengan banyak kalangan 
dari Belanda/Indo sendiri. Diberbagai kongres kebudayaan, orang seperti van Hinlopen Laberton aktif menulis dan berdiskusi dengan ningrat-ningrat Jawa. De Kat Angelino, dalam magnum opusnya Colonial Policy, merujuk pada proyek kolonial sebagai penyatuan dari spiritualitas Timur dengan kemampuan teknik Barat, sebuah pernyataan yang mendukung bentuk pembagian kekuasaan yang selama ini terjadi di Hindia Belanda (De Kat Angelino, 1931).

Adalah akar konservatif dan feodal inilah dimana nasionalisme Jawa bertumpu. Akar konservatisme itu tetap menjadi bagian sentral dalam pemahaman kita akan kebangsaan Indonesia. Penempatan kejayaan kebudayaan Hindu-Buddha berbarengan dengan penempatan ikon-ikon utama kebudayaan Jawa dan menjadi bagian erat dalam cara kita memahami kebangsaan Indonesia diabad ke-20. Ur-Indonesia yang menjadi fondasi dari nasionalisme, khususnya nasionalisme yang diusung oleh Orde Baru, tetap menjadi bagian dari pandangan kolektif kebangsaan Indonesia, walaupun ada kritikan bahwa pendekatan ini merupakan pengejawantahan daripada imperialisme Jawa. Disisi lain, pada masa pasca Orde Baru, ada usahausaha dari kalangan Islam untuk mencoba mendekonstruksi ur-nasionalisme Jawa Indonesia lewat usaha meng-Islam-kan zaman kejayaan pra-modern Indonesia. Tidak dapat dipungkiri betapa sentralnya, bahkan sampai sekarang, mitos ur-Jawa/Indonesia ini.

\section{Marxisme sebagai Obat Terhadap Irasionalisme Jawa: Tjipto Mangoenkoesoemo}

Marxisme memberikan kemampuan untuk menganalisis yang dianggap lebih efektif dibandingkan dengan irasionalisme yang ditawarkan oleh Teosofi, khususnya oleh banyak kalangan nasionalis Indonesia. Praktis semua nasionalis terkemuka Indonesia paham atau bahkan menganut Marxisme. Soekarno,
Sjahrir ataupun Hatta mungkin saja punya antipati terhadap gerakan Komunis yang seringkali tunduk pada keinginan Moskwa, tetapi sebagai sebuah pendekatan ilmiah, Marxisme merupakan sesuatu cara pandang yang menyegarkan dan memberikan analisis baru yang menyokong pandangan nasionalis yang revolusioner dan progresif daripada pendekatan ilmu pengetahuan Barat abad ke-19 yang berakar daripada rasionalitas pencerahan dan liberalisme klasik (Elson, 2008: ).

Tjipto Mangoenkoesoemo berada di generasi paling awal dalam kebangkitan nasional. Lahir di tahun 1886, Tjipto seangkatan dengan Soetatmo dan ikut berpartisipasi dalam pendirian Boedi Oetomo (Scherer, 1975: 106107). Tjipto Mangoenkoesoemo memiliki posisi yang unik: sebagai nasionalis awal, ia tertarik dengan pandangan-pandangan nasionalis Jawa, tetapi lalu melihat bahwa pendekatan irasional itu bukan merupakan jawaban terhadap ambruknya legitimasi cara pandang tradisional Jawa. Irasionalitas itu menutup diskusi dengan rasionalitas Barat. Cara Soetatmo menjawab serangan Barat adalah dengan menutup telinga dan mengangkat spiritualisme sebagai jawabannya. Tjipto ingin tetap berdiskusi dengan rasionalitas Barat dan bahkan menghantam serangan itu dengan serangan yang rasional pula. Disinilah manfaat daripada Marxisme dan serangkaian alat analisis yang ditawarkannya.

Terlihat bahwa cara pandang Tjipto berubah seiring dengan perkembangan kemampuan analitis Marxisnya.Tjipto muda seringkali berargumentasi dengan menggunakan wacana yang digunakan oleh rasionalitas Barat abad ke-19. Tapi seringkali ia menemukan bahwa dengan menggunakan wacana, terma dan logika yang digunakan oleh orang Belanda sendiri ia membenarkan serangkaian prasangka yang telah dibangun Belanda guna menempatkan diri mereka 
sebagai penguasa sah daripada Indonesia. (contoh dalam Tjipto, 1913 \& Tjipto, 1922).

Lewat Marxisme-lah sudut pandang ini dapat dibalikkan. Analisis kelas digunakan oleh Tjipto untuk menghantam ide utama akan masa lalu kejayaan Jawa sendiri. Majapahit digambarkannya sebagai sebuah masyarakat sakit dimana tradisi kasta Hindu membenarkan terjadinya penindasan antar warga berdasarkan kelas. (Tjipto, 1926/1927: 20) Oleh karenanya, kedatangan Islam yang egaliter merupakan sesuatu yang disambut oleh rakyat yang tidak sudi dizalimi oleh kelas penguasa. Dengan cara ini, Tjipto membalikkan logika utama yang telah dibangun selama ini: bahwa Islam membawa pemiskinan dan penurunan peradaban yang luhung yang dibawa oleh orang Indo-Eropa. Sebaliknya, Islam diangkat sebagai sebuah gerakan reformis dan progresif. India ditempatkan dalam posisi yang tidak bagus: daripada mewakili kejayaan peradaban masa lalu, ia merupakan bukti kegagalan daripada kalangan Arya untuk dapat melepaskan diri dari sudut pandang yang rasis ataupun pengekangan antar-kelas (Tjipto, 1928: 4). Ini adalah keberhasilan luar biasa yang akan digunakan oleh beragam nasionalis Indonesia untuk menghantam wacana utama kolonial. Marxisme dapat menggoyang akar-akar daripada rasionalitas ilmu pengetahuan Barat abad ke-19. Lewat analisis historis-materialis, Tjipto dapat membebaskan orang Indonesia dari kungkungan value-judgement etnografis yang telah dipasang oleh orang Belanda sebagai bagian inheren daripada ras Jawa/Indonesia. Pandangan ras diganti oleh kelas dan, sama pentingnya, cara pandang sejarah diubah daripada sesuatu yang menganggap bahwa keberhasilan dan kegagalan bangsa-bangsa itu terkait dengan vitalitas inheren dalam tiap-tiap ras ataupun bangsa yang berbeda-beda kepada sebuah pandangan yang menganggap bahwa semua manusia itu pada dasarnya sama dan bahwa akar-akar daripada perubahan sejarah terletak di suprastruktur logika ekonomi yang menaungi peradaban ataupun masyarakatnya.

Pembahasan Tjipto mengenai gerakan Samin memberi ide akan perbedaan cara analisis ini. Blumbergen menempatkan gerakan Samin, seperti kebanyakan analisis kolonial lainnya, sebagai ekspresi pra-modern (atau pra-organisasi modern). Menurut Tjipto, reaksi Samin adalah reaksi modern yang setara dengan gerakan Komunisme di Rusia dan Barat lainnya. Akar-akar insentif yang menggerakan orang-orang Samin untuk menolak hak milik individual dan pemajakan oleh negara itu merupakan ekspresi modern yang diejawantahkan sebagai akibat dari kesamaan kondisi struktural atau historis mateiralis yang dihadapi orang-orang dipedesaan Jawa yang pada dasarnya sama dengan yang dihadapi dipedesaan Eropa(Tjipto, 1918: 12-24). Dengan cara ini kondisi Jawa/Indonesia itu disamakan dengan kondisi Eropa. Perbedaan paling penting dibandingkan dengan pendekatan Soetatmo dan kalangan nasionalis Jawa adalah sifatnya yang revolusioner ataupun progresif. Jika Soetatmo yang konservatif menginginkan kelanjutan daripada proyek kolonial walaupun dengan perubahan perhubungan antara kalangan Jawa dengan Eropa, yang diinginkan oleh Tjipto dan nasionalis Indonesia lainnya adalah perubahan pada tingkat paling mendasar. Banyak diantara kaum nasionalis menempatkan akar daripada permasalahan terletak pada kapitalisme itu sendiri dan bahwa kolonialisme dan imperialisme merupakan pengejawantahan daripada logika kapitalis.

Pendekatan Marxis, beserta analisis yang dilakukan oleh banyak kalangan Marxis ataupun Sosialis pada awal abad ke-20 telah memberikan banyak sumbangsih terhadap cara nasionalis nonkoperatif kita memahami cara kerja dunia. Orang-orang seperti V.I. Lenin, Rosa Luxembourg dan RudolfHilferding memberikan gambaran yang menghubungkan kapitalisme dan liberalisme klasik dengan imperialisme, kolonialisme, rasisme dan 
fasisme. Membaca karangan Sjahrir ataupun Sukarno pada tahun-tahun 1930an memberikan pandangan yang amat berbeda daripada pandangan yang ditawarkan oleh nasionalisme Jawa. Daripada perasaan gugup ataupun resah akan runtuhnya mitos tradisonal Jawa, yang ada adalah pandangan progresif dan revolusioner yang melihat masa depan secara optimis. Daripada terkungkung dalam pandangan yang melihat orang Jawa sebagai ras indolen yang kurang pandai, pandangan Sosialis itu telah membebaskan manusia non-Barat sebagai agen perubahan.Oleh karenanya, pertentangan antara Noto Soeroto dengan kalangan nasionalis nonkoperatif itu begitu menarik.Pertama, karena Noto Soeroto adalah kalangan minoritas dibandingkan dengan kalangan nasionalis nonkoperatif itu. Sebagai pengemban dari konservatisme Jawa, pandangan Noto Soeroto dianggap pro-kolonial dan berbahaya.Sebagai pengemban nasionalis Jawa, Noto Soeroto punya posisi unik.

\section{Nasionalisme Jawa dimasa Non- kooperasi: Noto Soeroto}

Seperti Soewardi Soerjaningrat atau Soetatmo Soerioekoesoemo, Noto Soeroto adalah seniman Jawa sekaligus pemikir.Lahir di tahun 1888 sebagai anak dari Paku Alam V. Setelah menamatkan HBS, Noto Soeroto meninggalkan Hindia pada tahun 1910 guna menempuh studi hukum di Leiden, Belanda. Disanaia mendirikan organisasi bernama Oedaya yang aktif dalam mempertunjukkan kesenian Hindia, khususnya Jawa. Oedaya juga menerbitkan majalah yang banyak menuturkan ide-ide utama Noto beserta grupnya.Noto Soeroto adalah seorang penari profesional dan keaktifannya dalam kesenian merupakan bagian daripada usahanya untuk menjembatani jurang antara masyarakat Jawa/ Hindia dengan Belanda. Noto Soeroto adalah penerus daripada politik nasionalisme Jawa yang menganggap bahwa hubungan IndonesiaBelanda harus dipertahankan dalam kondisi yang lebih setara tetapi tetap sama. Sama dengan Soetatmo, ia pada dasarnya konservatif dan tidak menginginkan perubahan-perubahan yang bersifat revolusioner. Bergabung dengan gerakan yang bernama Rijkseenheid, Noto adalah bagian dari sekelompok orangorang konservatif baik Indonesia, Belanda ataupun Indo yang berkeinginan untuk menyesuaikan hubungan Indonesia-Belanda dalam satu kerangka hubungan budaya dan ketatanegaraan. (Koning, 1968; NieuwhuisDjajadiningrat, 1993: 41-75).

Pada awalnya ia aktif dalam Perhimpunan Indonesia, tetapi seiring dengan semakin menguatnya 'radikal nasionalis' didalam organisasi itu, pandangannya semakin tidak sesuai dengan mayoritas anggota. Ia dianggap oleh beberapa orang sebagai pembenci-pribumi (inlander hater) dan bahkan dituduh sebagai diperguna oleh penghasut Belanda yang ingin menimbulkan perpecahan dikalangan nasionalis (Soeroto, 1927: 139, 150).Noto Soeroto dikeluarkan dari PI pada tahun 1924. Perpisahannya dengan PI dianggapnya sebagai sebuah keputusan ideologis (Soeroto, 1925: 187).Ia menganggap bahwa nasionalisme adalah sesuatu yang secara inheren berbahaya karena akar-akarnya yang berdasarkan pada ras.Menurutnya, nasionalisme Barat yang diambil alih mentah-mentah oleh kalangan sebangsanya di PI merupakan sesuatu yang secara inheren berbeda dan tidak cocok dengan sifat bangsa Indonesia.Nasionalisme yang diimpor itu bersifat terlalu materialis dan teknis(Soeroto, 1925: 222-223).Ia mengandung didalamnya benih-benih yang berpotensi menyebabkan kehancuran dirinya sendiri dan manusia sekelilingnya.Ia menganggap bahwa jika dipaksakan, nasionalisme akan menyebabkan terjadinya kekerasan (Soeroto, 1925: 223). Apa yang ingin didorong oleh Noto, seperti Soetatmo, adalah kebangkitan dan kelahiran kembali kebudayaan. Kebudayaan yang ingin diangkat adalah kebudayaan Adiluhung Jawa, sebuah proyek reklamasi dari 
ilmu pengetahuan Barat. Budaya Adiluhung ini ditargetkan sebagai dasar atau akar daripada mitos kebangsaan baru (Soeroto, 1921).

Walaupun relatif populer dikalangan seniman, khususnya mereka yang aktif dalam grup Oedaya, Noto Soeroto tidak berhasil mendapatkan banyak dukungan dikalangan orang Indonesia. Pada tahun 1930, ia balik ke Hindia, meninggalkan isteri berkebangsaan Belandanya beserta anaknya. Di Hindia, ia kesulitan mendapatkan pekerjaan yang tetap dan bagus. Sebagai pemikir, ia terisolasi dan kesepian di Hindia. Ide-idenya tidak banyak mendapatkan perhatian baik dari kalangan orang Belanda ataupun orang Indonesia. Menguatnya radikalisme dikalangan nasionalis Indonesia diiringi dengan menguatnya nasionalisme ataupun rasisme dikalangan orang-orang Belanda dan Indo. Vaderlansche Club dan FSB mendapatkan pendukung kuat di Hindia Belanda, sementara itu represi daripada Gubernur Jenderal pasca pemberontakan Komunis tahun 1926 menyebabkan terjadinya penangkapan nasionalis non-koperatif pada tahun 1934. Usaha-usaha untuk menjembatani keterputusan kedua masyarakat itu ditahuntahun 1930an menjadi usaha yang semakin berat (Nieuwenhuis-Djajadiningrat, 1993: 41-75).

Disini terlihat bahwa selain konservatif, Noto Soeroto pada dasarnya adalah seorang yang anti-ekstrem, baik kanan maupun kiri (Soeroto, 1928). Ini bukan hal yang unik. Hampir semua pemimpin nasionalis Indonesia, baik Sjahrir, Sukarno, Hatta dan banyak lainnya, tampak tidak suka akan ekstremitas Komunis ataupun Fasis. Sebagian besar dari mereka menganut ideologi tengah yang mirip dengan ideologi Sosial Demokrasi. Mereka 'revolusioner' dalam artian bahwa akar-akar daripada permasalahan dunia seringkali didistilasi dari pandangan-pandangan sosialis yang melihat kapitalisme murni sebagai masalah. Dalam pandangan Marxis itu, hubungan antara struktur feodal dan kapitalisme internasional merupakan sesuatu yang menjadi akar daripada permasalahan yang menyebabkan kolonialisme dan rasisme. Disinilah letak perbedaan terbesar antara Noto Soeroto dan nasionalis Indonesia lainnya. Menurut Noto Soeroto, segala macam perubahan yang berdasarkan pada pandangan materialis punya potensi yang berbahaya. Menurutnya, daripada penghancuran dari feodalisme, Indonesia seharusnya merayakan feodalisme (Soeroto, 1928: 45). Ia menganggap bahwa demokrasi dan pelebaran partisipasi merupakan sesuatu yang secara inheren berbahaya dan menimbulkan akses bagi kaum demagog dan orang-orang yang punya niat buruk lainnya untuk berkuasa. Tak dapat dipungkiri bahwa perkembangan yang terjadi di Jerman dan beragam negara Eropa lainnya membuatnya ketakutan akan potensi munculnya kaum fasis ketika demokrasi dan partisipasi terhadap politik diperkenalkan. Sebaliknya Noto Soeroto menganggap bahwa apa yang sebaiknya dikembangkan oleh Indonesia adalah pemunculan kembali dari apa yang disebutnya sebagai Aristo-Demokrasi: sebuah demokrasi dimana pemilihan dibuat berjenjang dan yang dipilih dibatasi oleh orang-orang yang menurutnya sesuai untuk memimpin dari segi kebudayaan (Soeroto, 1931). Politik diganti oleh budaya dan batasanbatasan pemimpin dicari dalam local genious budaya Adiluhung. Praktisnya, ia mengingkan penerusan daripada feodalisme Jawa dan pendidikan yang lebih dalam terhadap budaya Adiluhung oleh kalangan pemimpin politik dan masyarakat.

Noto juga berbeda dalam pandangannya terhadap kapitalisme. Menurutnya, orang Indonesia mempunyai batasan kemampuan teknik dan salah satu cara terbaik untuk menangani keterbatasan ini adalah lewat persehubungan dengan orang Belanda seperti yang selama ini telah terjadi. Menurutnya, kapitalisme bukan merupakan sesuatu yang secara inheren buruk dan merupakan salah satu 
cara untuk dapat mensejahterakan masyarakat. Disini terlihat bahwa walaupun setuju dengan liberalisme klasik dan keberadaan kapitalisme internasional, Noto membedakan peran-serta orang Indonesia dengan Belanda (dan Tionghoa dan ras lainnya). Ia menekankan perbedaan kebudayaan sebagai akar daripada perbedaan peran kerja. Dalam pandangan ini, orang Indonesia yang spiritual membutuhkan bangsabangsa lain yang lebih kuat dalam bidang material dan teknik guna mencapai tujuan bersama dalam mewujudkan kemakmuran masyarakat. Pada analisis akhir, ia adalah seorang pro-kolonial. Hal ini terlihat dalam tulisan-tulisan akhirnya yang diterbitkan dalam majalah Udaya yang terbit pada tahun 1949-1950. Noto Soeroto dipenjara pada zaman Jepang. Kesehatannya menurun sepanjang tahun 1940an. Ia meninggal dunia pada tahun 1951 dalam keadaan miskin dan terlupakan. Tulisan-tulisannya Noto menunjukkan betapa konsistennya pandangannya setelah berakhirnya kolonialisme sekalipun. Ia menginginkan agar posisi keistimewaan daripada Kasunanan Surakarta dipertahankan. Ia mengingatkan akan bahaya daripada nasionalisme khususnya kekerasan terhadap minoritas Belanda, Indo dan Tionghoa. Ia menginginkan tetap berlanjutnya hubungan Indonesia-Belanda dalam beragam bentuk. Dan ia tetap menganggap bahwa nasionalisme Indonesia merdeka harus menggunakan budaya-budaya Adiluhung Indonesia. Ideide Adiluhung budaya Jawa didorong pula oleh nasionalis macam Ki Hajar Dewantoro (Soewardi Soerjaningrat) ataupun Soekarno. Noto Soeroto adalah bagian ekstrim daripada nasionalisme Jawa yang tetap hidup dalam nasionalisme Indonesia yang lebih besar (Fakih, 2012: 420-444).

Walaupun diposisikan diluar daripada tokoh nasionalis Indonesia, Noto Soeroto adalah prototip satu jenis nasionalis dan nasionalisme yang muncul di Indonesia pada awal abad ke-20. Sifat terbuka dan eksploratif nasionalisme ini menunjukkan betapa kompleks dan multi-polar-nya kemunculan kesadaran kebangsaan. Lebih-lebih, ia juga menunjukkan beragam akar-akar yang ada dalam proses pembentukkan nasionalisme Indonesia. Sumbangsih nasionalisme Jawa dalam nasionalisme Indonesia bukan saja harus diakui, tetapi juga mengharuskan kita untuk mereka ulang batasan dan akar-akar daripada nasionalisme yang kita pahami selama ini.Termasuk pula adanya akar-akar kiri, kanan maupun konservatif yang hidup dalam nasionalisme Indonesia sekarang.

\section{Nasionalisme Indonesia: Beragam tetapi dimana Individu?}

Tidak dapat dipungkiri bahwa nasionalisme Jawa merupakan salah satu aliran yang berkembang paling awal dalam sejarah nasional Indonesia.Walaupun bersifat konservatif dan mendukung feodalisme, akar ide nasionalisme Jawa itu tetap bertahan lama. Ide utama yang diutarakan oleh Noto Soeroto akan AristoDemokrasi yang membayangkan penguasaan kalangan ningrat atas masyarakat yang patuh mirip dengan diskusi pada zaman Demokrasi Terpimpin dan Orde Baru akan posisi rakyat dan elit. Elit disini mungkin diganti dari ningrat menjati ahli, tetapi kebanyakan ahliahli itu adalah keturunan keluarga ningrat yang dahulu. Hal lain adalah kepercayaan yang dalam bahwa persehubungan antara bangsa Timur dan Barat lewat semacam pembagian fungsi kerja merupakan sesuatu yang dilanjutkan, walaupun tidak dalam kerangka kerja kolonialisme. Konservatisme dari ide-ide persehubungan masyarakat dengan negara dimasa Orde Baru tampaknya amat kuat akarnya dengan ide-ide yang dibahas dalam nasionalisme Jawa.

Betapa pentingnya Marxisme dan Sosialisme sebagai sebuah pendekatan dan alat analisis dalam menghancurkan hegemoni wacana kolonial ilmu pengetahuan Barat juga merupakan sesuatu yang 
esensial dalam memberi amunisi terhadap gerakan nasionalisme Indonesia. Dalam semua gerakan dan ide yang dibahas diatas, semangat menciptakan ulang masyarakat baru adalah pendorong utama, bahkan dikalangan konservatif sekalipun. Yang tampak hilang dalam pembahasan semua tokoh diatas adalah posisi dari individu. Semua ide yang diangkat mengasumsikan bahwa setiap anggota dari bangsa Indonesia atau ras Jawa atau masyarakat Hindia Belanda setuju akan perubahan revolusioner yang ingin diejawantahkan. Kuatnya analisis Marxis yang menghubungkan liberalisme dengan kapitalisme dan kolonialisme menghilangkan kesempatan pembicaraan akan posisi dan hak individu. Sjahrir kemungkinan merupakan salah satu atau bahkan satu-satunya nasionalis yang mengangkat akan bahaya terhadap individu dari revolusi nasionalis yang ingin diwujudkan. Ini mungkin merupakan akibat daripada periode berkembangnya nasionalisme Indonesia. Diantara tahun 1908-1940an adalah masa ketika liberalisme klasik, demokrasi dan perdagangan bebas diganti dengan ide akan ras/kelas, otoritarianisme dan perekonomian nasional. Tidak dapat dipungkiri betapa kuatnya ide-ide Fasis ataupun Marxis masuk dalam pandangan-pandangan kebangsaan kita. Pada saat yang bersamaan, amat menarik pula untuk melihat betapa lemahnya ide-ide liberal dalam nasionalisme Indonesia.

\section{Daftar Pustaka}

Blumberger, Petrus, J. T. De nationalistische beweging in Nederlandsch Indie. Haarlem: Tjeenk Willink. 1931.

Buskens, L., \& Kommers, J. Dutch colonial anthropology in Indonesia.Asian Journal of Social Science, 35(3), 2007,h. 352-369.

Edgerton, F. "Sir William Jones: 1746-1794", Journal of the American Oriental Society, 66(3), 1946, h. 230-239.
Elson, Robert,The Idea of Indonesia: a history, Cambridge: Cambridge University Press: Cambridge. 2008.

Errington, Joseph. Linguistics in a colonial world: A story of language, meaning, and power. Oxford: Blackwell, 2008.

Farabi Fakih, "Conservative Corporatism: nationalist thoughts of aristocrats. The ideas of Soetatmo Soeriokoesoemo and Noto Soeroto", Bijdragen tot Land, Taal en Volkenkunde, 168(4), 2012, h. 420-444.

Furnivall, J. S. Netherlands India: A study of plural economy. Cambridge: Cambridge University Press. 1944.

Griffin, Roger. Modernism and Fascism: The Sense of a Beginning under Mussolini and Hitler. Houndmills: Macmillan. 2004.

Hitchcock, Michael \& Nyoman Dharma Putra,Tourism, Development and Terrorism in Bali. Aldershot: Ashgate. 2007.

Kartini,Door Duisternis tot Licht: gedachten over en voor het Javaansche volk, Amsterdam:Nabrink. 1976.

de Kat Angelino, A.D.A., Colonial Policy, The Hague:Martinus Nijhoff. 1931.

Koning, Roelie H.,Een gast in de Nederlandse letterkunde, disertasi di Universiteit vanAmsterdam, 1968.

King, Victor T. Some observation of the Samin Movement in North-Central Java.Suggestions for the theoretical analysis of dynamic social unrest.Bijdragen tot Taal, Land en Volkenkunde, 129(4), 1973, h. 457-481.

Lerner, Robert E. et.al.Western Civilization. Eleventh Edition. New York: W.W. Norton. 1988.

Müller, F. M., Biographies of Words and the Home of the Aryas. Longmans, Green. 1988.

Noto Soeroto, Rabindranath Tagore. Een biographisch schets, Amsterdam: W. Versluys. 1921.

Noto Soeroto, "Kleurschakeeringen uit Oedaya, Adhi Poestaka: The Hague, 1925. Noto Soeroto, "Nederland en Indonesie. Rede op den stamdag van het AlgemeenNederlandsch 
Verbond den 27 Maart 1925", Oedaya, no 23, $1925 \mathrm{a}$.

Noto Soeroto, De hoofdredacteur van "Oedaya" geroyeerd als lid van de "Indonesische Vereeniging" wegens anti-Indonesische gezindheid" in Oedaya, No. 20, 1925b.

Noto Soeroto, "Nederland en Indonesie" in Oedaya, no. 24, 1925c.

Noto Soeroto, "Idealisme in rassentoenadering. Toespraak gehouden bij de oprichting van de Utrechtsche afdeeling van het "NederlandschIndonesisch Verbond, op 24 Maart 1927", Oedaya, No. 48, 1927a.

Noto Soeroto, Door rasbewustzijn naar rassenverbroedering. Tespraak gehouden bij de oprichting van de Rotterdamsche afdeeling van het "Nederlandsch Indonesisch Verbond" op den 18den Mei 1927", Oedaya, No. 51, $1927 \mathrm{~b}$.

Noto Soeroto, "De ziel van den Inlander", Oedaya, No. 50, 1927c.

Noto Soeroto,"Mijn "vooze demagogie"', Oedaya, No. 54, 1927d.

Noto Soeroto, "Zonderlinge Strijdmethode", in Oedaya, No. 55, 1927e.

Noto Soeroto, Open brief aan mijn landgenooten," in Oedaya, No, 56, 1928a.

Noto Soeroto, "Het Javaansche volk en het rassenprobleem in Indonesie", in Oedaya, No. $62 \& 63,1928 b$.

Noto Soeroto, Nederland-Indonesie. Rijkseenheid of dominion-status? The Hague: NederlandschIndonesisch Verbond. 1931.
Outram, Dorinda, The Enlightenment. Third Edition, Cambridge: Cambridge University Press. 2013.

Raffles, T. S.,The History of Java. London: John Murray. 1830.

Roberts, D. D.,"Fascism, Marxism, and the question of modern revolution", European Journal of Political Theory, 9(2), 2010, h. 183-201.

Soetatmo Soeriokoesoemo, Sabdo Pandito Ratoe. Het recht is van den wijze. Weltevreden: Indonesische drukkerij. 1920.

Tjipto Mangoenkoesoemo, Iets Over den Javaan, Semarang:s.n. 1913.ם

Tjipto Mangoenkoesoemo, Saminisme. Een rapport, Semarang:Benjamins. 1918.

Tjipto Mangonekoesoemo, De wajang. Prae-advies, Semarang: Nationaal Indiërs Congres: Semarang. 1922.

Tjipto Mangoenkoesoemo, Het Communism in Indonesia, Bandung: Indonesia Moeda. 1926/1927.

deTollenaere, Herman O.A., The politics of divine wisdom. Theosophy and labour and women's movement in Indonesia and South Asia, 18731947.Disertasi PhD di Universiteit Nijmegen. 1996.

Tull, H. W."F. Max Müller and AB Keith:" Twaddle", the" Stupid" Myth, and the Disease of Indology".Numen, 6(1), 1991, h. 27-58.

Veth, P. J.,Java, Geographisch, Ethnologisch, Historisch, Haarlem: Erven F. Bohn. 1882.

Vickers, Adrian,Bali. A Paradise Created. Singapore: Periplus. 1986. 
